RESEÑAS 

Acta Hispanica (2019) 24: 157-160

\title{
LAS PELÍCULAS QUE VIO FRANCO
}

\author{
ANDRÁs LÉNÁRT \\ Universidad de Szeged \\ Caparrós Lera, José María - Crusells, Magí (2018). Las películas que vio Franco (y que no todos \\ pudieron disfrutar). Cine en El Pardo, 1946-1975. Madrid: Ediciones Cátedra, 312 páginas.
}

ISBN: 978-84-376-3807-2

\begin{abstract}
Es una tarea grata, pero también difícil escribir una reseña que es, a la vez, un homenaje a una persona cuya carrera científica ha caracterizado la vida de muchos, entre otros, la del autor de estas líneas. En 2018 falleció uno de los historiadores del cine español más prestigiosos, conocido, elogiado y admirado tanto en su país como a nivel internacional. La importancia de José María Caparrós Lera en el mundo académico es indudable: fue fundador-director del Centro de Investigaciones Film-Historia del Departamento de Historia y Arqueología de la Universidad de Barcelona y de la revista Filmbistoria (más tarde bajo el nombre Filmbistoria Online) desde 1991. Fue autor de 47 libros y más de 200 ensayos y artículos sobre la historia del cine español (desde la Segunda República pasando por el franquismo hasta la democracia) y universal (la guerra de Vietnam, la historia del grupo de terror irlandés IRA, incluso el cine de Woody Allen), un investigador infatigable que trabajaba aún durante las últimas fases de su enfermedad. En cuanto a sus temas explorados siempre ponía especial énfasis en tratar la cuestión escogida a partir de un doble enfoque: para él, cine e historia fueron dos terrenos inseparables, uno no podía existir sin el otro. Fue profesor visitante en varias universidades extranjeras y participante en congresos internacionales en todas partes del mundo - de hecho, su último viaje a un congreso extranjero le llevó en 2015 al Departamento de Estudios Hispánicos de la Universidad de Szeged, Hungría. Fue, además, creador de una escuela de historiadores de cine donde los miembros de su "familia" cinematográfica siguen cultivando la herencia de Caparrós, sobre todo dentro del marco de las publicaciones y congresos establecidos por él. Esta familia era y sigue siendo internacional: al lado de los investigadores españoles, incluye a varios extranjeros; por ejemplo, a un húngaro, el autor de esta reseña. Siendo maestro y amigo para sus colegas y discípulos, Caparrós Lera ha marcado las pautas a seguir para todos que seguimos sus huellas en el sendero donde se confluyen dos de las disciplinas más interesantes del campo de las humanidades, la historia y el cine.
\end{abstract}

Uno de los amigos y colegas más íntimos y frecuentes de Caparrós Lera ha sido Magî Crusells, otro gran especialista del cine español y autor de varios libros y ensayos. El profesor Crusells es también un notable investigador de las encrucijadas de la historia y 
Reseña - Las peliculas que vio Franco (y que no todos pudieron disfrutar). Cine en El Pardo, 1946-1975 de José María Caparrós Lera y Magí Crusells

el cine, enfocando, ante todo, en la Guerra Civil y el franquismo, también con puntos de vista internacionales. Actualmente, sigue las tradiciones emprendidas por Caparrós Lera, siendo su "heredero" tanto en la dirección del Centro de Investigaciones FilmHistoria como en la de la mencionada revista Filmbistoria Online, co-organizando congresos internacionales relacionados con los temas de historia y cine.

Entre los numerosos historiadores de cine que trabajan sobre temas cinematográficos en relación con la historia de España, José María Caparrós Lera y Magí Crusells han sido y siguen siendo los verdaderos referentes en este campo. No puede ser menos que un hecho simbólico que el último trabajo común de los dos investigadores -y el último de Caparrós Lera que fue publicado justo antes de su muerte- es una obra sobre una época y un tema que los dos conocen perfectamente. Se ha escrito mucho sobre el cine del franquismo, los temas y géneros, la censura y la propaganda del régimen, pero Las peliculas que vio Franco (y que no todos pudieron disfrutar). Cine en El Pardo, 1946-1975, con un prólogo escrito por el célebre historiador hispanista Paul Preston, nos ofrece un acercamiento distinto: en vez de enfocarse en la política y arte cinematográficos de la dictadura, se aproxima a los hábitos del dictador relacionados con el cine.

La importancia del cine para Francisco Franco no es una novedad: tanto en el campo de la diversión como en el de la propaganda, las películas ocupaban un lugar destacado entre los medios de comunicación. El cine poseía una fuerza primordial con la cual se podía ejercer enorme influencia sobre la sociedad. Sin embargo, el Caudillo tenía una relación estrecha con el cine incluso a nivel privado. Apareció en una película temprana como actor (La malcasada, Francisco Gómez Hidalgo, 1926), grabó escenas con su cámara en medio de una batalla en África y fue autor -bajo el seudónimo de Jaime Andrade- del guion del largometraje Raz̧a (José Luis Sáenz de Heredia, 1942). Se sabe desde hace mucho tiempo que a Franco le encantaban las películas extranjeras, sobre todo las de Hollywood, solía ver los filmes en proyecciones privadas y los comentaba con frecuencia. Además, le fascinaba salir en las revistas fotografiado con estrellas de cine estadounidenses, a algunos, como a Grace Kelly o James Stewart, les recibió personalmente en Palacio de El Pardo. Este libro es la primera obra extensa que nos da información detallada sobre los hechos y las circunstancias relevantes.

Según los datos recogidos por los dos autores, entre 1946 y 1975 el general Franco vio unas 2000 películas (1514 extranjeras y 465 españolas) en El Pardo: al menos dos largometrajes a la semana, y también documentales y algunos números del noticiario NO-DO. Las películas fueron elegidas por la esposa de Franco, Carmen Polo, asesorada por un productor de cine (Cesáreo González, fundador de la empresa productora Suevia Films) y un director (Rafael Gil) influyentes. Los dos fueron buenos amigos de la pareja, las obras de Gil aparecieron a menudo en la pantalla de su sala de proyección. El Caudillo pudo visionar muchas películas antes de someterlas al juicio de 
la Junta de Censura para ser "mutiladas" e incluso algunas -sobre todo extranjeras- que más tarde quedarían prohibidas por la misma Junta. Los largometrajes más controvertidos de la época -como los dirigidos por Luis Buñuel- también fueron proyectados en el hogar del dictador. Además, le encantaba filmar escenas familiares con su cámara amateur de $8 \mathrm{~mm}$, a veces también en las cacerías, algunas posteriormente serían sonorizadas con su propia voz como narrador. A las proyecciones asistían -al lado de Franco- su esposa, Carmen, su hija y los nietos, pero generalmente contaban también con la presencia de algunos invitados especiales: por ejemplo, amigos de la pareja, hombres del régimen como el almirante Luis Carrero Blanco o posteriormente Carlos Arias Navarro, o importantes representantes de la industria cinematográfica del país.

Debido a las tarjetas-invitaciones impresas que están disponibles, se sabe que en El Pardo se proyectaron todas las películas importantes del periodo. Entre los largometrajes ocuparon un puesto especial los dibujos animados de Walt Disney, algunos fueron presentados en el palacio mucho antes de su estreno español Cenicienta, por ejemplo, fue exhibida por el deseo propio del señor Disney. El cine infantil se proyectaba generalmente relacionado con un aniversario de uno de los nietos de los Franco.

Las fuentes del libro son varias. Las cifras oficiales ofrecidas por los guías del Palacio de El Pardo, los programas oficiales del Archivo General del Patrimonio Nacional facilitados por el subdirector de la institución, los expedientes del Archivo General de la Administración en Alcalá de Henares, entre otras. Además, los autores contaron con entrevistas concedidas por el mayordomo en El Pardo, un operador de cabina y un técnico cinematográfico del NO-DO. También recurrieron a antiguos testimonios de algunos miembros de la familia Franco. El libro nos ofrece fotos originales inéditas sobre la familia y el hogar del dictador, y también sobre los protagonistas de la vida política y cinematográfica del régimen, además de la publicación de informes, carteles, folletos y programas de mano originales. También encontramos un catálogo extenso de todas las películas vistas en El Pardo por los Franco y sus invitados, junto con la fecha de la proyección y los datos básicos del film, sea ese español o extranjero.

Como ha sido habitual en los libros anteriores de los dos autores, la obra no es una mera enumeración de nombres, títulos y datos; la información central se nos presenta en un ambiente contextual lleno de anécdotas tanto del mundo social como del cinematográfico, junto con varios detalles (muchas veces divertidos) que despiertan el interés de todos los lectores que se interesen por la historia y el cine de España. En cuanto a las películas que fueron proyectadas en El Pardo, el libro nos cuenta historias sobre su rodaje, sus vínculos con la política cinematográfica y con el contexto históricopolítico, sus problemas con la censura y con los hombres de régimen, es decir, tenemos 
Reseña - Las peliculas que vio Franco (y que no todos pudieron disfrutar). Cine en El Pardo, 1946-1975 de José María Caparrós Lera y Magí Crusells

acceso a un texto elaborado que reúne toda la información disponible para el investigador. Las entrevistas con las personas que fueron testigos de las proyecciones aportan detalles sumamente valiosos a través de los cuales se nos perfilan tanto algunos segmentos de la vida privada de Francisco Franco y su familia como el mundo complejo de la política e industria cinematográficas de las décadas de la dictadura.

Las películas que vio Franco es una digna despedida de José María Caparrós Lera, una obra imprescindible de Magí Crusells y una joya de la historiografía del cine español. 